\title{
Motivation Expectations and Motivational Styles Adopted by the Physical Education Teacher towards His Students: A Study in a Natural Context of Teaching and Learning
}

\author{
Nefaa Melliti1,2, Fayçal Zarrouk¹, Nizar Souissi³ \\ ${ }^{1}$ Institut supérieur de sport et de l'éducation physique de ksar said, Tunis, Tunisie \\ ${ }^{2}$ Institut supérieur de l'éducation et de la formation continue, Bouchoucha, Tunisie \\ ${ }^{3}$ Observatoire national du sport Tunisien, Tunis, Tunisie \\ Email:n_souissi@yahoo.fr
}

How to cite this paper: Melliti, N., Zarrouk, F., \& Souissi, N. (2016). Motivation Expectations and Motivational Styles Adopted by the Physical Education Teacher towards His Students: A Study in a Natural Context of Teaching and Learning. Creative Education, 7, 2226-2250.

http://dx.doi.org/10.4236/ce.2016.715219

Received: June 13, 2016

Accepted: September 23, 2016

Published: September 26, 2016

Copyright $\odot 2016$ by authors and Scientific Research Publishing Inc. This work is licensed under the Creative Commons Attribution International License (CC BY 4.0).

http://creativecommons.org/licenses/by/4.0/ cc) (i)

Open Access

\section{Abstract}

The effects of the teacher's expectations on students' motivation remain an area of investigation where the results are still controversial. This article presents the main results of a study on the relationship between motivation expectations of Physical Education (PE) teachers and the behaviors exhibited toward their students in a natural context of PE teaching in Tunisia (gymnastics cycle). The theoretical framework is based on three categories of work: 1) the work on the "Pygmalion effect", 2) research relating to self-determination theory and classroom interactions expressed by quantity, content and the style of verbal communication between teachers and students, and 3) the work examining the links between teachers' initial expectations towards the students and these interactions. The objective of this study is to analyze the consequences of pre-existing and lightly studied expectations regarding the motivation on the frequency, content and motivational style (i.e., controlling vs. autonomy-supportive) interactions that a PE teacher has with students. Seven hundred and thirty students from all classes of second cycle basic education and their thirty teachers were observed during gymnastics classes. The teachers' motivation expectations and self-determination index of students were measured at the beginning of the cycle. The teacher-student interactions were recorded during each session (50 minutes) corresponding to a teacher (thirty sessions on the whole) and encoded using two instruments. The main results show that: a) teachers have expressed more communications with high expectations than low ones; b) the teachers' expectations are positively related to technical instructions and autonomy-supportive style and negatively to unfavorable affective feedback and a controlling style. These different dimensions mentioned above make up important mediators of "Pygmalion effect" that certain studies have noted in PE. 


\section{Keywords}

Expectations, Self-Determined Motivation, "Controlling” Style,

Autonomy-Supportive Style, Differential Treatment

\section{Introduction}

Naturally the teacher is supposed to develop different expectations (positive vs. negative) since each student is different. In terms of learning, the goal of any desired "differentiating function" is to allow everyone to reach his full potential and drive the weakest, most disadvantaged or unmotivated to master the core skills (Pieron, 1993, 1996). The differentiating function should indeed take on a more organized aspect offering fair treatments and settle in the heart of didactic-pedagogic system. However, regular class observation shows that the teacher is more differentiated (e.g., Pieron et al., 1998). This spontaneous differentiation based on daily interactions with each teacher, or their expectations towards each student can contribute to advantaged or disadvantaged treatment which does not match the desired differentiation. Various studies conducted in a natural classroom situation have also quantified the "teacher-effect" whose weight is estimated at about $16 \%$ on acquisitions (e.g., Duru-Bellat \& Ming, 1994). In terms of differentiated pedagogy, the teacher is required to differentiate his education and "make a difference" by the behaviors he implements, the nature of his interactions and communications (verbal/nonverbal) with students, the educational and motivational climate he creates, and the assessments he carries out (e.g., Good \& Brophy, 2000 for a general synthesis; Cloes et al., 2004; Pieron, 1993; Sarthou, 2003; Hagger et al., 2003 in the field of sport and Physical Education (PE)). While some of these studies show significant differences between the most "effective" teachers and those who are less, some also highlight the variability of behavior and attitudes of the same teacher based on his classroom students (e.g., Sarrazin, Tessier, \& Trouilloud, 2006; Sarrazin, Trouilloud, Tessier, Chanal, \& Bois, 2005). In other words, this teacher does not give the same attention and interest, show the same warmth and flexibility, offer the same content and instructions or return the same evaluations (Feed-back) for all students in the class (e.g., Weinstein \& Middlestadt, 1979; Weinstein, 1985; Carreiro Da costa et al., 1998). What are the reasons behind this differential treatment? Why is the teacher likely to generate inequalities between students? Why do some students seem to receive preferential treatment, while others seem to be neglected, left behind (offside) and even despised? If the communication style is strongly questioned, should it be necessary that a $\mathrm{PE}$ teacher revises his concepts and establishes a personal reflection on his practice and its impact on students?

\subsection{The Teacher's Expectations}

The teacher acts, among other phenomena, by his expectations regarding competence, skill, autonomy and the student's effort. The expectations that the teacher develops to- 
wards his students is one of the factors explaining their differentiated behaviors. The psychologists have in fact studied in detail what Robert Merton called in 1948 "self-fulfilling prophecy". This concept means "an initially false belief of the situation that raises new behaviors consistent with this mistaken belief" (Merton, 1948). In the educational context, the phenomenon is known as the "Pygmalion effect" (Rosenthal \& Jacobson, 1968), and characterizes every perception or expectation of the teacher who changes the behaviors of students in a manner consistent with the original expectation.

For about forty years, the role of the teacher's expectations is increasingly a major research topic in an academic context (for summaries, see Good \& Brophy, 2000; Jussim \& Eccles, 1992; Jussim, et al., 1998). Some of these were conducted in PE classes or in a competitive sporting context (for summaries, see Horn et al., 1998; Martinek, 1989, 1991; Trouilloud \& Sarrazin, 2003; Sarrazin, Trouilloud, \& Bios, 2005). In these contexts, researchers (e.g., Good \& Brophy, 2000; Horn et al., 1998; Jussim, 1986; Martinek, 1989) agree on the existence of four steps through which expectations can become self-fulfilling:

- Early in the year, the teacher develops expectations about the performances or the different future attributes of students (e.g., skill, effort) from the information he has (e.g., in PE, the tests record of physical and motor skills, the diagnostic assessment of the beginning of a cycle);

- These expectations lead to a differential treatment: they affect the quality and quantity of interactions with students;

- This differential treatment is perceived by the students;

- If it persists over time, it affects their motivation (e.g., Trouilloud \& Sarrazin, 2002) and performance (e.g., Trouilloud et al., 2002) in the sense of the initial expectations of the teacher.

This differential treatment (reflecting the differentiating function) of the teacher may be positive or negative. For example, the high expectations of a teacher can generate superior performance, as low expectations can undermine students' performance (Trouilloud et al., 2006; Sarrazin, Tessier, Pelletier, Trouilloud, \& Chanal, 2006).

In most explanatory models of "self-fulfilling prophecy", the expectations themselves would not influence the student, but rather the specific behaviors of teachers caused by these expectations (Jussim, 1986). The models used in the educational context assume that teachers will act and react differently with students based on the expectations they formulate on them (Brophy \& Good, 1974; Snyder, 1984; Cooper, 1979; Darley \& Fazio, 1980; Jussim, 1986; Rosenthal, 1974). Harris and Rosenthal (1985) found that the differences linked to the proposed content and task difficulty on one hand, and the emotional climate created by the teacher on the other hand, were those whose impact on the student's performance were the most important.

In sporting context, the majority of research on the expectations effect of the supervisor (PE teacher/coach) focused on the relationship between expectations and the behaviors displayed by the coach or PE teacher (e.g.; Trouilloud, 2002; Sarrazin, Trouilloud, \& Bois, 2005). At the start of the school year (or sports season) and in the beginning of a teaching sequence (or training), either the teacher or the coach is required to 
prepare students ranking of the class (or sporting team) according to their level (physical and motor skills tests, diagnostic evaluation before addressing the training sessions). Then the behaviors exhibited by the supervisor were carefully observed and coded during PE lessons (or trainings) using tools such as Coaching Behavioral Assessment System (CBAS; Smith et al., 1977). Finally, both variables and behaviors were taken into consideration.

The retained conclusions of previous studies partially confirm that there is henceforth a substantial evidence on the existence of a differential treatment of supervisors in connection with the expectations they develop towards their students (or athletes) (For a detailed review of this literature, see Horn et al., 1988; Martinek, 1991; Sarrazin, Trouilloud, Tessier, Chanal, \& Bois, 2005; Trouilloud, 2002). The supervisors can create differences in favor of "high expectations" at the socio-emotional climate they establish during pedagogical interactions. They seem to establish a warm and comforting environment with students (or sportsmen) they perceive competent: they are more flexible, encouraging, appreciative, attentive and smiling (e.g., Babad et al., 1982; Babad, 1993). They also tend to offer them richer tasks and teaching content, more difficult and varied and thus facilitating the efficient and effective movement skills. Therefore, and in general, they seem more willing to interact with them by providing a more positive and emotional climate.

Nevertheless supervisors interact less frequently with "low expectations": they pay them less attention, usually criticize them at failure (e.g., Babad et al., 1982), display less friendly interactions, show them less nonverbal indicators of support (e.g., smile) and have colder and more anxious voice intonation (e.g., Babad et al, 1982; Martinek \& Johnson, 1979). They also seem less demanding, send back briefer evaluations that provide less information about the performance or the performed technique, and easily accept poor or incorrect performances (e.g., Martinek \& Karper, 1982). Furthermore they tend to encourage them less frequently and create a more negative emotionally climate. Thus supervisors tend to give less emotional support to "low expectations".

These differences in socio-emotional climate involve both verbal communication process (i.e., praise) and non-verbal communication process (i.e., smile, nod, eye contact, to be closer to student). In other words, the "communication" of the supervisors' expectations, which may have an impact on the student mainly on his cognitions, behaviors and performances, should not go unnoticed in the classroom (or sports team).

\subsection{The Controversies Reported in Literature}

Although research has shown clear and important evidence on the existence of differential treatment based on supervisors' expectations, however, it should be noted some inconsistencies in some previous work. Some studies have found no treatment singularity regarding the teacher's expectations (Spallanzani, 1995). In others, the supervisor can provide more encouragement and technical feedback for the "low expectations" so that he could motivate students (Horn, 1984; Martinek, 1980, 1988; Karper \& Martinek, 1983). 
Among deductions and remarkable explanations for this inconsistency, it is important to note those of Sarrazin, Trouilloud, Tessier, Chanal, \& Bois (2005). These authors cited methodological reasons emphasizing that most of the research has ignored the person who was responsible for the interaction in the relationship teacher-student or coach-athlete. Thus, the highest interaction rates found in some studies for the "high expectations" may in part be due to the fact that these students (or athletes) initiate more interaction with their teacher (or coach). Indeed, the best students of a class (or a team) may be more likely to ask their teacher/coach to seek additional information to progress further, improve performance and/or confirm their level. Given these conditions, it is difficult to refer to a "treatment favor" from the part of the teacher. Therefore it seems necessary and essential, from a methodological point of view, to consider the person (teacher vs. student) that initiates interaction and constitutes the educational action. In the same perspective, it is possible that the higher rate of positive feedback returned by the teacher towards "high expectations" is simply related to the fact that they actually achieve better performances than "low expectations". The most competent students probably achieve more satisfactory performances than the lowest or incompetent, and thus they are more inclined to their teacher's positive feedback (Horn, 1984). Again, in order to speak of a special treatment, it seems important to control the level of performance or the initial attitude of the student to see if "at the same level", the teachers' expectations are still connected to specific behaviors (Trouilloud \& Sarrazin, 2003; Sarrazin, Trouilloud, Tessier, Chanal, \& Bois, 2005). Moreover, these two consensual ideas allowed to emerge the purpose of this study which is interested in the process of the Pygmalion effect in general with a special attention to the teacher's expectations related to the motivation and differential treatment that have been little studied so far in a natural context. Indeed, it is likely that supervisors develop expectations related to other characteristics or dimensions than the competence of their students (or sportsmen).

In addition to performances, other elements such as the ability to make efforts, invest and work independently (student/athlete: hard-working and autonomous) are among the things that "count" for a teacher/coach, as shown by the works on educational attitudes (e.g., Wolfe \& Engel, 1978; Yee \& Frutcher, 1971). Teachers even seem to have a differential treatment and display remarkable and clear preferences for hard-working students, despite previous acquisitions and limited abilities (e.g., Covington \& Omelich, 1979). In a PE study, Biddle and Goudas (1997) found similar results: they have shown that PE Teachers clearly preferred teaching motivated and hard-working students regardless of their abilities and results in this subject. The motivation therefore seems an important feature of the picture that the teacher draws about his students (Famose 2001; Sarrazin, 2001). It is possible that expectations regarding students' motivation are an organizing and catalyst factor of the behaviors he manifests in the classroom (Sarrazin, Trouilloud, Tessier, Chanal, \& Bois, 2005). As a result, sensitizing the teacher (or coach) on behaviors which could create an environment communicating not only his competence expectations but also his motivation expectations, and thus establishing a 
climate which offers a fair treatment and not of favor (from the perspective of students) seems to be another central part of reflection and important work.

\subsection{Objectives and Hypotheses}

The main objective of this study was to verify if the PE teacher's behaviors are associated with motivation expectations (effort/autonomy) that the teacher formulates regarding his students within teaching/learning natural situations. This term will be used in its ordinary meaning in the educational field: expectations regarding the student's ability to make efforts and engage spontaneously in school tasks (like the autonomy expectations are proved to be highly correlated with effort expectations $(\mathrm{r}>0.80, p<$ $0.001)$, these two dimensions were grouped and called "motivation expectation". The second objective of the present study was to enlighten and broaden the nature of behavioral coding of PE teacher to rehabilitate the function of evaluation. Previous work focused largely on the number and content of the interactions between teacher and students (e.g., number of feedback organizational vs. Technical vs. evaluative, etc.). Or according to Babad (1998), the key element in the communication of the teacher's expectations is not so much the content of interactions that the style with which these interactions are performed. In other words, differences in treatment due to the teacher's expectations would focus on tone, heat and emotions with which the teacher interacts with students (Sarrazin, Trouilloud, Tessier, Chanal, \& Bois, 2005). In short, these differences would stand at the motivational profile expressing the attitudes and the motivational style of the teacher and the motivational climate he creates.

Two motivational styles have been particularly studied in recent years within the scope of the self-determination theory (SDT), representing another look at the motivational climate (for a review of literature in the field of education, see Reeve, 2002; Reeve et al., 2004; Ryan \& Deci, 2000, 2002; and in the field of sport and PE, see Biddle et al., 2001; Mageau \& Vallerand, 2003; Sarrazin, Trouilloud, Tessier, Chanal, \& Bois, 2005; and Bryan \& Solmon, 2007; Ryan \& Deci, 2007): autonomy-supporting style and controlling style. A teacher who supports autonomy is closer, more positive, more flexible and explanatory. Whereas a "controlling teacher" tends to be in charge of everything, more pressed, more negative and motivate by pressure (Reeve, 2002). The results of previous work (see for a review of literature Reeve, 2002; Reeve et al., 1999; Ryan \& Deci, 2000; and for a synthesis, Sarrazin Tessier, \& Trouilloud, 2006) highlight the benefits for a student's motivation, when a teacher adopts an autonomy-supportive style rather than a controlling one. The Analyses seeking to understand the links between the supervisor's motivation expectations and his motivational style are rarely studied. According to our theoretical basis of this research, very few studies have sought to extend this line of research. We can mention the study of Pelletier and Vallerand (1996) in an experimental context and the study of Sarrazin, Trouilloud, Tessier, Chanal, \& Bois (2005) in a natural educational environment. In the first, the experimenters make the students, playing the role of a supervisor, believe that they should teach subordinates something which was either intrinsically motivated (e.g., interested in the task) or extrinsically motivated (e.g., practicing the task only for money). The results showed that 
supervisors who taught intrinsically-motivated subordinates displayed more self supportive behaviors than those with extrinsically motivated subordinates. While this study provides interesting information on the motivation expectations-behavior links, it does not shed lights on the phenomenon in a natural teaching situation. However, the second study (Sarrazin, Trouilloud, Tessier, Chanal, \& Bois, 2005) has considered this research limitation and was developed specifically in a teaching natural context to understand the links motivation expectations-motivational style adopted by the teacher (supporting-autonomy style vs. controlling style). It is important to note that this study has provided some support to the link between motivation's expectations of the teacher and the differential treatment that he is likely to bring with his students while using more consistent methodological procedures. Nevertheless, the second study has some limitations. Indeed, the population size of teachers was reduced to seven teachers and the students from various classes practiced different physical activities (volley ball, table tennis, badminton and indoor football). It is possible that the specificity of each sport can change the nature of the relationships between teachers and children. However, we are persuaded in this research to extend the study of Sarrazin and his collaborators by monitoring the limits outlined previously and performing our experiments in a teaching natural context in order to obtain the greatest possible ecological validity. A new sample of thirty teachers and seven-hundred thirty students were observed in PE at the same cycle of physical activity (gymnastics). According to the postulates of SDT, a variety of behaviors controlling and supporting independence were coded and mapped to the teacher's expectations for motivation and formed at the beginning of an eight-session cycle. Finally, data were coded according to a system taking into account the inter-teacher variability and the quantity of transmitted communications. Thus, and according to the theoretical framework of self-fulfilling prophecies and that of self-determination theory, we applied the general hypothesis of a teacher's differential treatment in class expressed at the time by the quantity, content and styles of verbal communications towards students for whom he supplies high vs. low expectations of motivation. In a more precise manner, and according to the theoretical and empirical work presented, the following hypotheses were made:

- Hypothesis 1: Regarding the frequency of interactions containing communications, PE teachers, in a gym cycle, interact and communicate more with "high expectations" than to "low expectations" because they correspond more to their concept or definition of a "good" student in gymnastics (Biddle \& Goudas 1997; Covington \& Omelich, 1979);

- Hypothesis 2: Regarding the content of these interactions during the transmission of technical instructions (criteria suggestion/performance criteria), teachers express more useful information to the performance of a motor skill or good performance for "high expectations", for the same reason as in hypothesis 1, according to studies of Horn et al (1998), Martinek (1991) and Sarrazin, Trouilloud, Tessier, Chanal, \& Bois (2005).

- Hypothesis 3: Regarding the style of interactions, teachers support more autonomy towards "high expectations" and are more controlling towards "low expectations", 
according to studies of Pelletier and Vallerand (1996) and Sarrazin, Trouilloud, Tessier, Chanal, \& Bois (2005).

Given the methodological limitations in previous works (e.g., Horn, 1984), we followed the approach used in the study of Sarrazin, Trouilloud, Tessier, Chanal, \& Bois (2005), which assumes that this differential treatment occurs after taking into account 1) the person who is responsible for interaction and 2) the level of students' motivation. Indeed, in this work, only interactions (verbal communication) triggered by the teacher will be selected, and the initial self-determination index (SDI) of students will be measured in order to neutralize its potential influence on the behavior of teacher.

\section{Method}

\subsection{Sample}

The population of this study consisted of 344 boys and 386 girls (mean age $=13.52 \pm$ 1.67 years), from thirty classes of the second basic education cycle: the preparatory cycle of basic education, and their teachers (17 women, 13 men; mean age $36.67 \pm 8.63$ years) practicing in the Governorates of Medenine, Tozeur, Gabes, Sfax, Monastir, Tunis, Ariana, Ben Arous, Manouba and Bizerte.

\subsection{Approaches}

This study was performed in two steps. Initially, and after the first class of eight-session gymnastics cycle (duration of a session: 50 minutes), teachers' expectations regarding the motivation of each of their students were measured using a questionnaire distributed to each teacher and self-determination index was noted for each student using another questionnaire. Secondly, and in the middle of the cycle (4th/5ème session), each session (thirty sessions on the whole) was filmed by HF lapel microphone, synchronized with the image to save the teacher-student interaction continuously using a digital camcorder. To avoid disturbing the teacher and students, the camera was placed in a fixed location with a large angle, but at a distance that could identify the student(s) concerned by the interactions. All classes were filmed during a session ( $2 \mathrm{nd} / 3 \mathrm{rd}$ ) before recording the data to familiarize the study protagonists with the used equipment. To reduce the bias associated with the Hawthorne effect (e.g., Adair et al., 1989) for the teacher (e.g., behaviors' change due to the presence of an observer), the experimenter (inspector/academic advisor) introduced himself to the teacher as a student conducting a survey on PE students' motivation, without any allusion to the Pygmalion effect.

\subsection{Measures}

\subsubsection{Teacher's Expectations Regarding His Students' Motivation}

After the first session (start of cycle competition), teachers completed a questionnaire designed to measure their expectations of effort ("In your opinion, will this student make efforts during the gymnastics cycle?") and autonomy ("Do you think this student will be able to work independently and autonomously during this cycle?"), in respect of each of their students on a 7-point scale with (1) "No, not at all" and (7) yes, absolutely. 
Since the expectations of autonomy were found to be positively correlated with expectations of effort $(\mathrm{r}>.80, p<0.001)$, these two items were grouped together and referred to as "motivation expectation".

\subsubsection{Self-Determined Motivation for Gymnastics}

At the beginning of the cycle, students in each class completed a questionnaire designed to measure the level of self-determination in the gymnastics activity. This questionnaire, developed from motivation scale to sports (MSS, Briere et al., 1995) and motivation scale to education (MSE, Vallerand et al., 1989), consists of 28 items measuring 7 types of motivation of self-determination, namely:

- The intrinsic motivation to knowledge (KIM), measured with two items such as "I attend gymnastics class to learn new sports techniques";

- The intrinsic motivation to achievement(AIM), measured with two items such as "I attend gymnastics class to improve some of my weaknesses";

- Intrinsic motivation related to sensations(SIM), measured with four items like "I attend gymnastics for the fun that this activity brings to me";

- The identified extrinsic motivation(IDEM), measured with three items such as "I attend gymnastics because what I learn in PE will help me later";

- Introjected extrinsic motivation (INEM), measured with four items like "I attend gymnastics because I feel guilty if I did not succeed in this activity";

- Extrinsic motivation with external regulation (EREM), measured with three items such as "I attend gymnastics mainly because I'll have a score";

- The amotivation (AM) measured with three items such as "I do not see why I'm in gym class; if I could, I would give it up".

- All the responses were brought into a 7-point scale (1) "totally disagree" to (7) "strongly agree". The self-determination index (SDI) used by some authors (e.g., Vallerand \& Losier, 1999) was calculated. The SDI is obtained by weighting the scores on each subscale according to their position on the continuum of self-determination according to the following formula:

$$
\mathrm{SDI}=[(2 *(\mathrm{SIM}+\mathrm{KIM}+\mathrm{AIM}) / 3)+\mathrm{IDEM}]-[((\mathrm{ERME}+\mathrm{INEM}) / 2)+(2 * \mathrm{~A})]
$$

It should be mentioned that in previous studies, this index has presented psychomotor characteristics and a very satisfactory predictive validity (e.g., Vallerand, 1997). Whether in academic context (e.g., Vallerand \& Bissonette, 1992), sports (e.g., Sarrazin, Vallerand, Guillet, Pelletier, \& Cury, 2002) or PE (e.g., Ntoumanis, 2001, 2005; Hagger \& Chatzisarantis, 2007), the more motivation was self-determined (certified by a high index), the more the individual tried hard and persevered.

\subsubsection{Coding System of Teacher-Student Interactions}

To be more precise, only interactions 1) triggered by the teacher and 2) addressed to one student were coded. The target student of the communication was identified during the coding phase through ID photographs. The verbal exchanges between teachers and students were coded using two observation grids from earlier work. The content of 
the communication was coded from an observation grid of the study Sarrazin and colleagues and inspired from Coaching Behavior Assessment System (CBAS, Smith et al., 1977), the works of Martel, Brunelle and Spallanzani (1994) on the observation of PE learning climate and the works of Sarthou (2003) on learning theories and teaching tools. This grid classifies and distinguishes six main categories of communication (Table 1).

\subsubsection{The Communication Style/Motivational Style}

In agreement with the postulates of the theory of self-determination (e.g., Ryan \& Deci, 2000), the work of Reeve in the school context (Reeve, 2002; Reeve et al., 1999), those Mageau and Vallerand (2003) by Vallerand (2007) and those in sports context of Sarrazin, Trouilloud, Tessier, Chanal, \& Bois (2005) in PE, communications were then coded a second time with another observation grid to identify the communication style "autonomy-supportive" vs. "controlling" teachers (Table 2).

\subsection{Coding Reliability and Data Processing}

The Interactions containing communications were coded by thirty observers (inspectors and supervisors), in the image of an observer for each session without being able to consult. To estimate the intra-coders reliability, each observer coded the same session again after four weeks. The analysis of Kappa coefficients Cohen (Bakeman \& Gottman, 1997) reveals a good intra-coders homogeneity (between .75 and $.98 ; M=85$ ) for all

Table 1. Coding of six categories of communications (content of verbal communications).

\begin{tabular}{|c|c|c|}
\hline $\begin{array}{l}\text { Communication } \\
\text { Category }\end{array}$ & Focus & Examples \\
\hline $\begin{array}{l}\text { Organizational } \\
\text { Communications }\end{array}$ & They do not influence the performance, of type: & $\begin{array}{l}\text { "Go to the right column" } \\
\text { "Place yourself on profile to do the } \\
\text { parade" }\end{array}$ \\
\hline $\begin{array}{c}\text { Technical } \\
\text { Communications }\end{array}$ & $\begin{array}{l}\text { The technical instructions in connection with the } \\
\text { criteria of/performance/suggestion, intended to } \\
\text { improve the skills and strategies used by the } \\
\text { student, the type: }\end{array}$ & $\begin{array}{l}\text { "keep your arms fully extended and } \\
\text { the gap between the hands parallel } \\
\text { to the length of the shoulders in } \\
\text { handstand" } \\
\text { "Try to contract your abdominals } \\
\text { and buttocks" }\end{array}$ \\
\hline $\begin{array}{l}\text { Positive Evaluative } \\
\text { Communications }\end{array}$ & $\begin{array}{l}\text { To strengthen and confirm the behavior or the } \\
\text { success of a motor task, such as: }\end{array}$ & "Well done, good job!" \\
\hline $\begin{array}{l}\text { Negative Evaluative } \\
\text { Communications }\end{array}$ & $\begin{array}{l}\text { Intended to show the teacher's disapproval of the } \\
\text { student performance (criticism followed by } \\
\text { technical information), the type: }\end{array}$ & $\begin{array}{l}\text { "Bad body alignment" } \\
\text { "awful, rolls forward, without the } \\
\text { head touches the mat" }\end{array}$ \\
\hline Positive Affective & $\begin{array}{l}{ }^{*} \text { Designed to stimulate and encourage students to } \\
\text { achieve the objectives of the teacher, of the type: }\end{array}$ & $\begin{array}{c}\text { "Come on, try again; go, courage, } \\
\text { you can do it" }\end{array}$ \\
\hline Communications & $\begin{array}{l}{ }^{\star} \text { In case of incompetence, the teacher made it } \mathrm{t} \\
\text { clear he expects more from the student, like: }\end{array}$ & $\begin{array}{l}\text { "No problem, believe in yourself, } \\
\text { you'll do it" }\end{array}$ \\
\hline $\begin{array}{l}\text { Negative affective } \\
\text { Communications }\end{array}$ & $\begin{array}{l}{ }^{*} \text { They are offensive or sarcastic, usually as a result } \\
\text { of inappropriate behavior or incorrect execution, } \\
\text { type: } \\
{ }^{*} \text { The teacher made it clear to the student that he } \\
\text { does not expect a big thing, type }\end{array}$ & $\begin{array}{l}\text { “stupid, you're really good at } \\
\text { Nothing" } \\
\text { “even if you try to make an omelet, } \\
\text { it'll be a disaster" }\end{array}$ \\
\hline
\end{tabular}


categories of behaviors.

To test the hypothesis of differential treatment based on the teacher's expectations, both groups of students were formed from the "average" level expectation of teachers, calculated in each class (e.g., Horn, 1984; Solomon et al., 1996; Sarrazin, Trouilloud, Tessier, Chanal, \& Bois, 2005). Those located above and below the average level were considered respectively "high expectations" $(n=355)$ and "low expectations" $(n=375)$. A

Table 2. Coding of communication style (controlling style vs. autonomy-supportive style) adopted by the teacher.

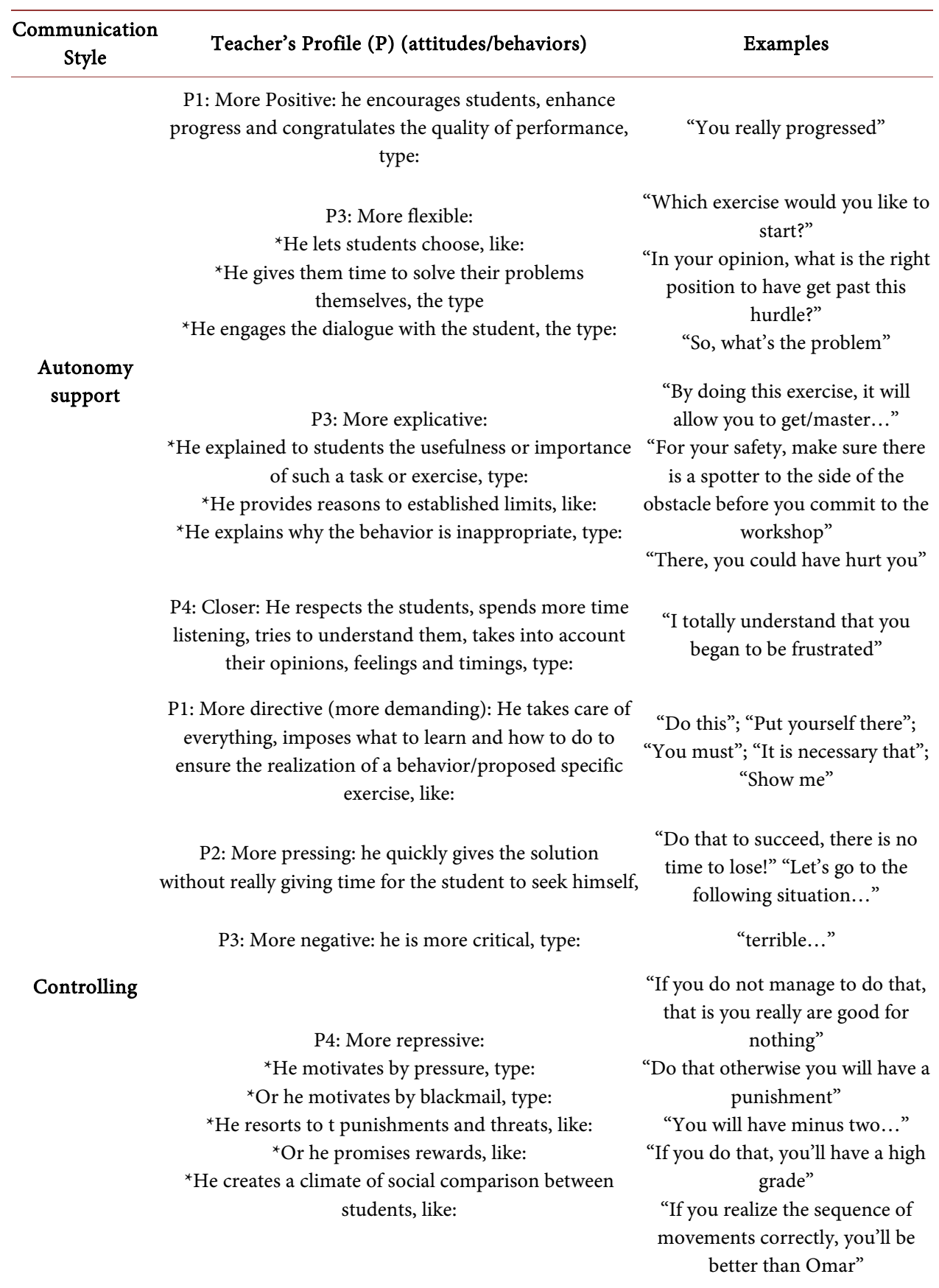


comparative statistical analysis from the frequency factor (teacher motivation expectations) and two modes (high vs. low) was conducted on the number of interactions/communications triggered by the teacher using the overall chi-square test $\left(\mathrm{x}^{2}\right)$. Two other comparative analyzes from the frequencies were then performed 1) on the six categories of communication (content), and 2) on both types of style.

In each of these three analyzes, the initial self-determination index of the student has been used as an explanatory variable (independent) to see if the differential treatment appeared at the same level of motivation.

\section{Results}

A total of 2695 interactions between teachers and students and 3781 verbal communications were collected on all thirty sessions observed (interaction can contain multiple communications).

The average number of interactions received per student is 3.7 while the average number of communications per student is 5.2.

Table 3 shows the percentage of the frequency of communication of teachers towards their students according to the level of motivation expectations (high vs. low).

The frequency of communications with low expectations $(\mathrm{n}=1834,48.505 \%)$ was not significantly different $\left(x^{2}=3.38\right)$ from that with high expectations $(n=1947,51.495 \%)$.

We observed that teachers have committed as much communication with the high expectations as with low ones.

Figure 1 shows the distribution in percentage and frequency of different types of collected communications concerning the content. The results show a predominance of organizational communications $(\mathrm{n}=1346,35.6 \%)$ and technical $(\mathrm{n}=1289,34.1 \%)$ compared to other types of communications.

Figure 2 shows percentage and frequency distribution of communications relating to both types of communication styles "controlling vs. autonomy-supportive" The results shows the teachers' resort to a predominantly controlling style.

Regarding the content of communications, statistical analysis by the Person chisquare shows that high expectations differ significantly from the low ones $\left(\underline{\mathrm{ddl}}=5, \mathrm{x}^{2}=\right.$ 67.84, $p<0.001)$.

Table 4 indicates the frequency and percentage distribution of different types of communications relating to the content based on the level of motivation of expectations adjusted to the level of self-determined motivation.

Table 3. Frequency ( $\mathrm{n}$ ) and percentage (\%: Distribution) of oral communications initiated by teachers towards their students according to the level of motivation expectations (ME) (high vs. low).

\begin{tabular}{|c|c|c|}
\hline & \multicolumn{2}{|c|}{ Communications Frequency $n=3781$} \\
\hline & ME high & ME low \\
\hline $\mathrm{n}$ and $\%$ & $194751.495 \%$ & $183448.505 \%$ \\
\hline Comparing communication frequency with high & \multicolumn{2}{|c|}{$\chi^{2}=3.38$} \\
\hline and low ME & \multicolumn{2}{|c|}{ NS } \\
\hline
\end{tabular}




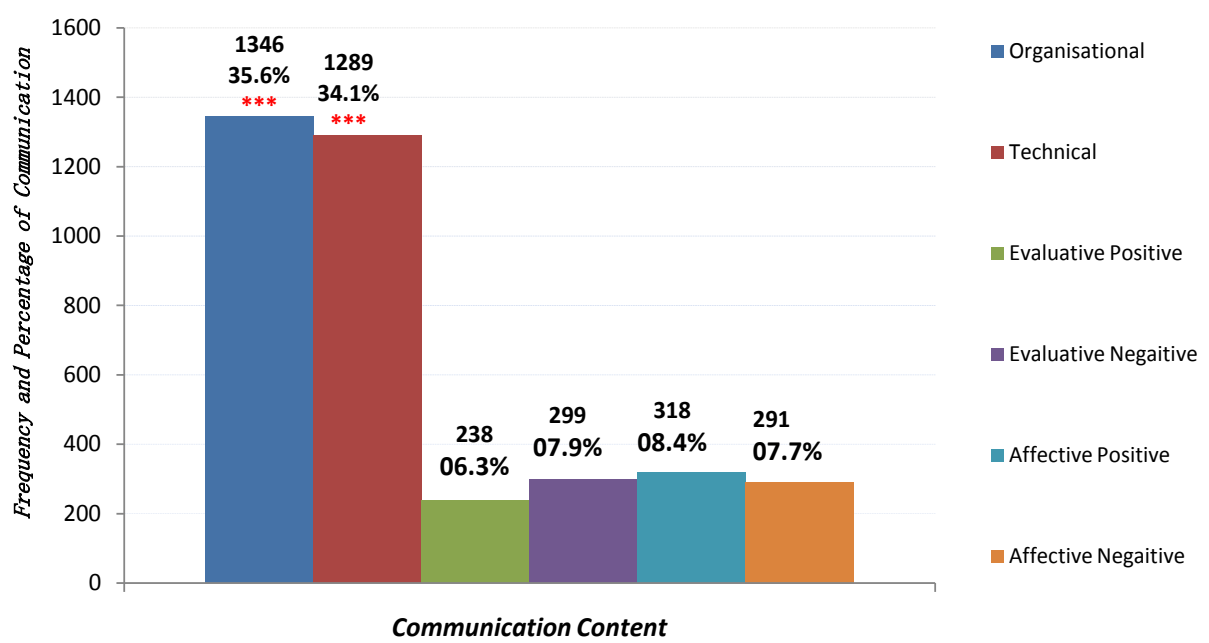

Figure 1. Frequency and percentage distribution of different types of communication related to content $\left({ }^{* * *}: p<0.001\right)$.

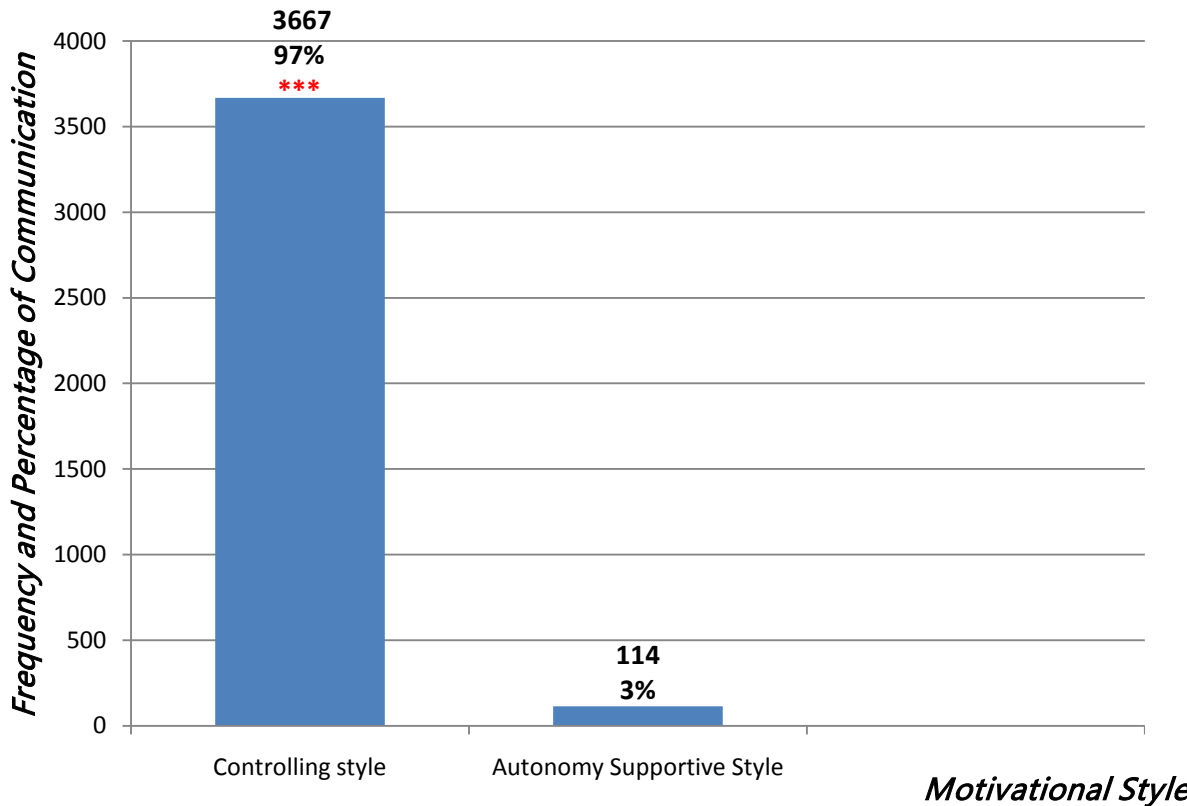

Figure 2. Frequency and percentage distribution of different types of communication related to motivational style (controlling vs. autonomy support) $\left({ }^{* * *}: p<0.001\right)$.

The results show that the content of communications seems to differentiate based on the teacher's expectations about both categories of communications: 1) technical communications $\left(\mathrm{x}^{2}=37.21, p<0.001\right)$ and 2$)$ negative affective communications $\left(\mathrm{x}^{2}=\right.$ $32.33, p<0.001)$.

About communication style, we observe that high expectations frequency is significantly lower than that of low expectations ( $\left.\underline{\mathrm{df}}=1, \mathrm{x}^{2}=46.96, p<0.001\right)$.

Table 5 shows that teachers used more autonomy-supportive behaviors with "high expectations" ( $\left.\mathrm{x}^{2}=40.56, p<0.001\right)$ and controlling behavior with low expectations $\left(\mathrm{x}^{2}=\right.$ $11.02, p<0.001)$. 
Table 4. Frequency and percentage distribution (adjusted according to the index of self-determination of students) of different types of communication relating to the content based on the level of teacher expectations (high vs. low).

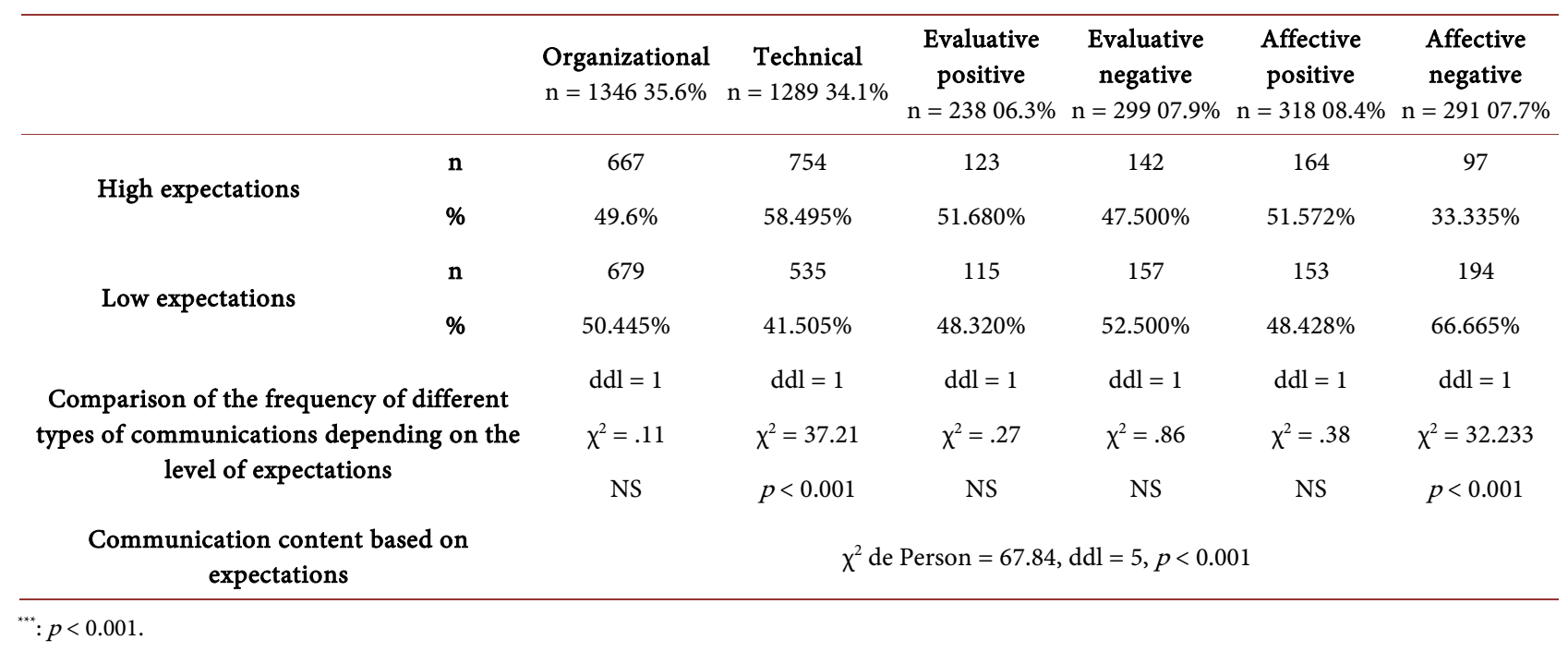

Table 5. Frequency and percentage distribution (adjusted for self-determination index) of communications about motivational style (controlling vs. autonomy support) according to the level of expectations.

\begin{tabular}{|c|c|c|c|c|}
\hline \multicolumn{3}{|c|}{ Communication Style } & \multirow{2}{*}{$\begin{array}{c}\text { Controlling style } \\
1733\end{array}$} & \multirow{2}{*}{$\begin{array}{c}\begin{array}{c}\text { Autonomy } \\
\text { supportive style }\end{array} \\
91\end{array}$} \\
\hline \multirow{4}{*}{$\begin{array}{l}\text { Motivation } \\
\text { expectations }\end{array}$} & \multirow{2}{*}{ High expectations } & $\mathrm{N}$ & & \\
\hline & & $\%$ & $47.260 \%$ & $79.825 \%$ \\
\hline & \multirow{2}{*}{ Low expectations } & $\mathrm{N}$ & 1934 & 23 \\
\hline & & $\%$ & $52.740 \%$ & $20.175 \%$ \\
\hline \multirow{3}{*}{\multicolumn{3}{|c|}{$\begin{array}{c}\text { Comparaison of communication styles frequency based on } \\
\text { motivation expectations }\end{array}$}} & $\mathrm{ddl}=1$ & $\mathrm{ddl}=1$ \\
\hline & & & $\chi^{2}=40.56$ & $\chi^{2}=11.03$ \\
\hline & & & $p<0.001^{* * *}$ & $p<0.001^{* * *}$ \\
\hline \multirow{2}{*}{\multicolumn{3}{|c|}{ Style de communication en fonction des attentes }} & \multicolumn{2}{|c|}{$\mathrm{ddl}=1$} \\
\hline & & & \multicolumn{2}{|c|}{$\chi^{2}$ de Person $=46.91, p<0.001$} \\
\hline
\end{tabular}

${ }^{* * *}: p<0.001$

\section{Discussion}

In order to associate the notion of self-fulfilling prophesies and self-determination theory, this study and like Sarrazin, Trouilloud, Tessier, Chanal, \& Bois (2005) has sought to focus on the relationship between PE teachers' expectations with regard to motivation of each of their students, and identify the behaviors they adopt in a natural teaching situation. Specifically, we were interested to find out if the PE teachers' expectations of motivation led to differential treatment of students according to:

- The amount of communications that contain interactions initiated by teachers;

- Content;

- And communication style (the motivational style). 
This study extends previous works, first, relying on another expectation which might organize the behaviors of the teacher even his differentiating feature: motivation expectations. The majority of previous studies have measured expectations of "performance" or "competence" (students may get good results or less in class). Insofar as the effort and spontaneous commitment shown by the student are of central importance for teachers (e.g., Biddle \& Goudas, 1997; Covington \& Omelich, 1979; Wolfe \& Engel, 1978; Yee \& Frutcher 1971; Sarrazin, Trouilloud, Tessier, Chanal, \& Bois, 2005), we are convinced that it seems heuristic to consider this variable (e.g., Sarrazin, Trouilloud, Tessier, Chanal, \& Bois, 2005). Furthermore, this study extended previous works, in observing beyond different types of communication, the "style" of these types. In agreement with the postulates of self-determination the theory (e.g., Reeve, 2002; Reeve et al., 2004; Ryan \& Deci, 2000), we observed associations between the expectations of motivation (effort/autonomy) of teacher and his adopted motivational style (autonomy-supportive style vs. controlling style) in a "Tunisian" natural context of PE teaching. The results are discussed in the light of three hypotheses mentioned above.

\subsection{Motivation Expectations and Communication Frequency}

Regarding the frequency of communications, contrary to our first postulated hypothesis, the results show that teachers of this study triggered as much communication with students marked by "high expectations" as with "low expectations" $\left(x^{2}=3.38\right.$, insignificant). At the first observation, expectations of motivation developed by teachers have not had an effect on the number of communications they initiated with their students. This result does not replicate previous work in sports context (Horn, 1984; Solomon et al., 1996) which showed that coaches interacted more with athletes who benefited from higher proficiency expectations. Indeed, previous studies in the field of sport observed the behavior of team sports coaches in competitive contexts in which the primary objective is victory and optimizing the performance of the team. For this reason, we can assume that the coach neither pursues the same objectives nor maintains the same relationship with his players (athletes) as PE teacher with his students. In a competitive environment, with the performance is the goal, it is understandable that the coach relies on the best elements ("high expectations"), those he considers most likely to ensure the success of the team. However this result replicates the earlier study in context of PE by Sarrazin, Trouilloud, Tessier, Chanal, \& Bois (2005). These authors point out that in context of $\mathrm{PE}$ and in educational situation, in contrast to the sports context, the teacher is probably more focused on the acquisition of knowledge and the solicitation of all students (conceptualization of teaching). Thus he could be more inclined to provide equity in the distribution of his interactions, communications and treatment of students. It also seems that he is more likely to follow this more focused approach when it comes to an activity as gymnastics. Indeed, gymnastics is characterized by a structural and safe specificity. The teacher is required to be more "present" and "communicative" with all its students to ensure their safety and the "structure" of the class. The distribution results of different types of communications received, based on their continuous 
and style, justify this argument (see Figure 1 and Figure 2). Indeed, they show a predominance of organizational communications (35.6\%) and technical (34.1\%) compared to other types of communications, using a mostly controlling style (97\%).

Thus, the context and characteristics of physical activity and sport (gymnastics: the case of our study) could explain this difference for the works mentioned.

However, the presence or absence of "quantitative" difference in communications initiated by the teacher, do not present a sufficient explanatory and tangible element of differential treatment of favor. The lack of a "quantitative" difference in the amount of communications in the case of our research does not mean that the teacher does not establish differential treatment in respect of his students (Sarrazin, Trouilloud, Tessier, Chanal, \& Bois, 2005). In fact the teacher can maintain the same number of interactions (or communications) with two students, but he is very critical even repressive with one and positive, warm and close with the other. In other words, the differences may relate to the content (Jussim et al., 1998; Trouilloud \& Sarrazin, 2003; Sarrazin, Trouilloud, Tessier, Chanal, \& Bois, 2005) and/or style (Babad, 1993) of interaction. Therefore understanding these two variables appear as a relevant perspective.

According Sarrazin, Trouilloud, Tessier, Chanal, \& Bois (2005), previous results in PE are not very consistent, and most studies have methodological limitations to the extent that they did not control the person who was the source of the interaction and the true level of students. As already noted above, it seems difficult to deal with preferential treatment when the student who is the origin of interaction, or when his true level makes him unable to receive some feedback from his teacher. Consequently, in this research, and like Sarrazin, Trouilloud, Tessier, Chanal, \& Bois5 (2005), we ensured to code just the interactions in which the teacher was the source, as well as the real motivation level of the student.

\subsection{Motivation Expectations and Content Interactions}

According to our second hypothesis and some previous works (e.g., Horn et al., 1998; Martinek, 1991; Sarrazin, Trouilloud, Tessier, Chanal, \& Bois, 2005), differences in content interactions were approved. Teachers in our study have provided more technical information such as "keep arms straight" for students marked by high expectations (autonomous and hard-working) and more negative affective communications like "you're really good at nothing" to students marked by low expectations (lazy and unmotivated). We believe that this differential treatment leads to create (or increase) the differences in motivation, investment, involvement and ultimately in performance among students. Indeed, previous studies (e.g., Horn, 1985; Martinek \& Karper, 1984; Sarrazin, Trouilloud, Tessier, Chanal, \& Bois, 2005) showed that the information relevant to the performance improvement (e.g., the technical instructions: criteria of realization, suggestion) have positive effects on perceived competence (perceived skills), motivation and students success. Conversely, lack of emotional support or negative emotional feedback communication can permanently affect the image that students have of themselves (self-esteem, self-image), and therefore their investment and per- 
formance during the PE classes. The causes of this differential treatment are likely to be sought in the greater proximity or similarity that teachers can feel towards students they believe to be motivated and hard-working (Sarrazin, Trouilloud, Tessier, Chanal, \& Bois, 2005). They may experience a stronger desire and show more willingness to advance the students who seem to share their work value and importance of academic achievement (e.g., Jussim, 1986; Jussim et al., 1998). On the other hand, they seem more inclined to despise and ignore those who do not share these values. It is important to remember that these results were observed after controlling the real level of student motivation. Our results showed that the SDI was not connected to any of the teacher's behavior. In contrast, it is associated with expectations $\left(\mathrm{x}^{2}=22.03, \mathrm{ddl}=1, p<0.001\right)$. In other words, the beliefs of teachers about student motivation, more than the real motivation of the students, develop some differentiated behaviors of teachers. That is those judged as motivated receive better treatment than little or unmotivated students even if it is not really the case, as has been demonstrated by Pelletier and Vallerand (1996).

\subsection{Motivation Expectations and Motivational Style}

In accordance with our third hypothesis, and in agreement with the study of Pelletier and Vallerand (1996) and that of Sarrazin, Trouilloud, Tessier, Chanal, \& Bois (2005), the results of our work show that teachers particularly use a more "controlling" style (they are more stressed, repressive, critical and negative to ensure the realization and safety of the task) with students to whom they emit low motivation expectations $1\left(\mathrm{x}^{2}=\right.$ 40.56, $p<0.001)$. On the other hand, they employ a style that appeals to autonomy (they are more positive, closer, more flexible) with students marked by high expectations $\left(x^{2}=11.03, p<0.001\right)$. Despite the fact that teachers in our study are more controlling $(\mathrm{n}=3667)$ than autonomy-supportive $(\mathrm{n}=114)$, it was unexpected to find autonomy support level as low toward high expectations $(n=91)$. Although the direction of the correlation between expectations and autonomy-supportive style is consistent with the postulated hypothesis, it should be noted that the frequency of behaviors supporting autonomy is low (n: 114/3\%). It seems that the PE teachers of this research, as well as those of the study of Sarrazin, Trouilloud, Tessier, Chanal, \& Bois (2005), are more familiar and better trained in using controlling motivational strategies than those supporting independence. The results show that all teachers in this study essentially use organizational communication and technical feedback to control their students. Together, these categories represent $2 / 3$ of Communications and $69.7 \%$ of all their behaviors. Therefore, in this research, this motivational style (supporting autonomy) in contrast to controlling motivational style does not seem to be an indicator of a differential treatment of students.

However, these different aspects confirm the idea that motivation expectations would be an organizing factor of the motivational style of PE teacher. This differential treatment at the motivational climate interactions can influence student behavior. According to the cognitive evaluation theory (CET) (Biddle et al., 2001; Deci \& Ryan, 1985; 
Deci et al., 1991; Ryan \& Deci, 2000), behaviors supporting autonomy and positive feedback can nourish and enhance perceived competence and self-determined motivation of students while negative behavior and feed-back may hinder self-determined motivation. Nevertheless, the impact of the "motivation expectation" factor should be moderated; this means that this factor in itself does not account for the majority of PE teachers to use a controlling "style". This finding corroborates the work of Sarrazin, Trouilloud, Tessier, Chanal, \& Bois (2005). Previous work (e.g., Mageau \& Vallerand, 2003; Pelletier et al., 2002; Reeve, 2002) listed other factors that explain the high proportion of motivational profiles of teachers displaying "controlling" behaviors, while the benefits of feeding-autonomy style were outlined and approved by research (e.g., Reeve, 2002) (see Sarrazin, Tessier, \& Trouilloud, 2006 for a summary). It may seem ironic to realize that the way how teachers teach is the opposite of what their students need.

If on one side the teacher's motivation expectations are not based on objective indicators, or if they are connected to other backgrounds which have no connection with the determination and the future performance (skin color, dress, physical attractiveness, gender, affiliation...), thus the teacher's expectations can be inaccurate and will affect the adopted motivational style (see Dusek \& Joseph, 1983 for a meta-analyis). On the other side, certain individual characteristics, such as ideologies, beliefs or purposes may affect the adopted style (Sarrazin, Trouilloud, Tessier, Chanal, \& Bois, 2005). Earlier studies have shown that such rejection of a "liberal" concept of education was associated with a tendency to authoritarianism (e.g., Nachtscheim \& Hoy, 1976). On the other hand, the belief that an "authoritarian" or "controlling" teacher is more effective than a cooperative one (who listens to his students and is closer to them), as well as low self-determined motivation for work, are also characteristics of a teacher who is associated with a controlling style (e.g., Pelletier et al., 2002; Reeve, 2002).

In addition, contextual characteristics and/or institutional such as the institution pressures (overloaded classes, disciplinary management), and the characteristics of the physical activity itself (e.g. constraints in the management of student' safety in gymnastics or shot put) tend to reduce the flexibility of the teacher in terms of innovation and pedagogical variability (Pelletier et al., 2002) and can lead the teacher to be partially controlling. Moreover, even if the teacher had a greater degree of freedom, one can question the feasibility of this principle. We believe that the needs, interests and aspirations of students are very diverse, and it does not seem possible, in such a context, to build teaching behaviors and adopt a motivational style that can satisfy the intrinsic interest of each and the desire to be responsible for his own behavior (self-determination).

\section{Conclusion and Prospects for Research and Field}

The results highlighted some support to the link between PE teacher's motivation expectations and the differential treatment that he brings with his students:

- First, from the quantity perspective: Teachers express as much communications with "high expectations" as with "low expectations". 
- Second, from the content perspective: "autonomy" and "effort" expectations seem to be positively associated with the technical information they provide. However, they are negatively associated with negative emotional evaluations (the negative derogatory critics).

- Finally, from the perspective of motivational style: motivational expectations are positively associated with an autonomy-supportive style while they are negatively associated with a controlling style.

These different retained dimensions allowed establishing unambiguously the existence and the ecological validity of the Pygmalion effect in PE teaching. Thus, they could constitute mediating processes of this phenomenon that some studies have found in PE or sports context (e.g., Trouilloud \& Sarazin, 2002; Trouilloud, 2002; Sarrazin, Trouilloud, Tessier, Chanal, \& Bois, 2005).

\subsection{Research Prospects}

It should be worth noting that the effect of expectations of motivation should be moderated. Indeed, they do not alone explain this outcome. It remains to conduct future studies to see if the dimensions mentioned above should be complemented by other factors such as individual characteristics, contextual characteristics and/or institutional characteristics of the physical activity, in order to determine and define the role of the teacher's motivation in regard with students.

It is also important to relativize the results. The observation shows that the differences in socio-emotional climate involve not only verbal communications but also nonverbal behaviors. So one of the interesting developments would be to employ more representative grids of existing interactions manifested by the PE teacher during the session.

\subsection{Field Perspectives}

Despite the socio-political revolution manifested in Tunisia and calling for freedom and democracy, the PE teacher has not get rid of his "authoritarian" and "controlling" behavior and does not seek to provide adequate space of freedom to nourish self-determined motivation.

However, telling simply what the teachers should do to develop specific and positive expectations towards all students and communicate or solicit their motivation is clearly not enough for this to occur (Reeve, 2002). It seems that this must be accompanied by a didactic-pedagogic and educational reflection from the part of the teaching team on the didactic treatment of sport and physical activity and how to change the strategies for learning/teaching and motivational strategies to encourage and support innovative initiatives of supervisors and researchers and also ensure the equitable learning environment. Besides this reflection is insufficient unless it is reinforced by an individual reflection from the teacher since he is the major player in the practical field and what it conveys to students especially teenagers whose status (competent/incompetent; hardworking/lazy/motivated/unmotivated) and identity are strongly questioned. 
Physical activities constitute undoubtedly a means of education, social integration and health. This requires operationalization of the teachers objectives (didactic transposition) passing through a theoretical reflection, construction and innovation of professional tools (Sarthou, 2003) such as PE project, class project, observation grids and diagnostic evaluation at the beginning of each school year and each teaching unit. Being armed with personalized pedagogic and didactic tools, the teacher can be involved in the development of accurate and flexible expectations and in differentiating an educational approach so that students can be treated fairly and offered individualized content for each to ensure his autonomy.

Finally, on the ground, the teacher nowadays must be above all a "motivator" while leading and managing the class safely by asserting his authority (positive control) and also adapting to the risks of teaching conditions and "educational slippage". However, if the student's future autonomy must be the goal of any supervisor, why not think within the school and PE context of offering students an "autonomy" and "controlled" operation guaranteeing harmony between the margin of freedom and the "structure" of the class in which the student learns to propose, design projects and achieve them with the teacher's assistance while respecting others.

\section{References}

Adair, J. G., Sharpe, D., \& Huynh, C. L. (1989). Placebo, Hawthorne, and Other Artifact Controls: Researchers' Opinions and Practices. Journal of Experimental Education, 57, 341-335. http://dx.doi.org/10.1080/00220973.1989.10806515

Babad, E. Y., Rosenthal, R., \& Inbar, J. (1982). Pygmalion, Galatea, and the Golem: Investigations of Biased and Unbiased Teachers. Journal of Educational Psychology, 74, 459-474. http://dx.doi.org/10.1037/0022-0663.74.4.459

Babad, E. Y. (1998). Preferential Affect: The Crux of the Teacher Expectancy Issue. In J. Brophy (Ed.), Advanced in Research on Teaching: Expectations in the Classroom (Vol. 7, pp. 183-214). Greenwuch, CT: JAI Press.

Babad, E. Y. (1993). Teachers' Differential Behaviour. Educational Psychology Review, 5, 347376. http://dx.doi.org/10.1007/BF01320223

Bakeman, R., \& Gottman, J. M. (1997). Observing Interaction: An Introduction to Sequential Analysis (2nd ed.). Cambridge: Cambridge University Press.

http://dx.doi.org/10.1017/cbo9780511527685

Biddle, S., Chatzisarantis, N., \& Hagger, M. (2001). Théorie de l'autodétermination dans le domaine du sport et de l'exercice physique. In F. Cury, \& P. Sarrazin (Eds.), Théories de la motivation et pratique sportive. Etat des recherches (pp. 19-55). Paris: PUF.

Biddle, S. J., \& Goudas, M. (1997). Effort Is Virtuous: Teacher Preferences of Pupil Effort, Ability and Grading in Physical Education. Educational Research, 39, 350-355.

http://dx.doi.org/10.1080/0013188970390310

Briere, N., Blais, M., Pelletier, L., \& Vallerand, R. (1995). Developpement et Validation d'une Mesure de Motivation Intrinsèque, Extrinsèque et d'Amotivation en Contexte Sportif: L'Echelle de Motivation dans les Sports (EMS). International Journal of Sport Psychology, 26, 465-489.

Brophy, J., \& Good, T. (1974). Teacher-Student Relationships: Causes and Consequences. New York: Holt, Rinehart \& Winston. 
Bryan, C. L., \& Solmon, M. A. (2007). Self-Determination in Physical Education: Designing Class Environments to Promote Active Lifestyles. Journal of Teaching in Physical Education, 26, 260-278. http://dx.doi.org/10.1123/jtpe.26.3.260

Carreiro da Costa, F., Marques da Costa, C., Diniz, J. A., \& Piéron, M. (1998). Uneanalyse de la qualité du feedback. In C. Amade-Escot, J.-P. Barrué, J.-C. Bos, F. Dufor, M. Dugrand, \& A. Terrisse (dir.), Recherches enEPS: Bilan et perspectives (pp. 215-224). Paris: Éditions EP\&S.

Cloes, M., Ledent, M., \& Piéron, M. (2004). Motiver pour éduquer, un éclairage qualitatif. In G. Carlier (dir.), Si l'on parlait du plaisir d'enseigner l'education physique (pp. 65-73). Montpellier: Éditions AFRAPS.

Cooper, H. (1979). Pygmalion Grows Up: A Model for Teacher Expectation Communication and Performance Influence. Review of Educational Research, 49, 389-410. http://dx.doi.org/10.3102/00346543049003389

Covington, M. V., \& Omelich, C. L. (1979). It's Best to Be Able and Virtuous Too: Student and Teacher Evaluative Responses to Successful Effort. Journal of Educational Psychology, 71, 686700. http://dx.doi.org/10.1037/0022-0663.71.5.688

Darley, J. M., \& Fazio, R. H. (1980). Expectancy-Confirmation Processes Arising in the Social Interaction Sequence. American Psychologist, 35, 867-881. http://dx.doi.org/10.1037/0003-066X.35.10.867

Deci, J. M., \& Ryan, R. M. (1985). The General Causality Orientations Scale. Self-Determination in Personality. Journal of Research in Personality, 19, 109-134. http://dx.doi.org/10.1016/0092-6566(85)90023-6

Deci, E. L., Vallerand, R. J., Pelletier, L. G., \& Ryan, R. M. (1991). Motivation and Education: The Self-Determination Perspective. The Educational Psychologist, 83, 642-650.

Duru-Bellat, M., \& Mingat, A. (1994). La variété du fonctionnement de l'école: Identification et analyse des "effets-maître". In M. Crahay, \& A. Lafontaine (Eds.), Évaluation et Analyse des Etablissements de Formation (Pages). Bruxelles: De Boeck.

Dusek, J., \& Joseph, G. (1983). The Bases of Teacher Experiences: A Meta-Analysis. Journal of Educational Psychology, 75, 327-346. http://dx.doi.org/10.1037/0022-0663.75.3.327

Famose, J. P. (2001). La motivation en éducation physique et en sport. Paris: Armond Colin/VUEF.

Good, T. L., \& Brophy, J. E. (2000). Looking in Classrooms (8th éd.). New York: Longman.

Hagger, M. S., \& Chatzisarantis, N. L. D. (2007). Intrinsic Motivation and Self-Determination in Exercise and Sport. Champaign, IL: Human Kinetics.

Hagger, M. S., Chatzisarantis, N. L. D., Culverhouse, T., \& Biddle, S. J. H. (2003). The Processes by Which Perceived Autonomy Support in Physical Education Promotes Leisure-Time Physical Activity Intentions and Behavior: A Trans-Contextual Model. Journal of Educational Psychology, 95, 784-795. http://dx.doi.org/10.1037/0022-0663.95.4.784

Harris, M. J., \& Rosenthal, R. (1985). Mediation of Interpersonal Expectancy Effects: Thirty-One Meta-Analyses. Psychological Bulletin, 97, 363-386. http://dx.doi.org/10.1037/0033-2909.97.3.363

Horn, T. (1984). Expectancy Effects in the Interscholastic Athletic Setting: Methodological Concerns. Journal of Sport and Exercise Psychology, 6, 60-76. http://dx.doi.org/10.1123/jsp.6.1.60

Horn, T., Lox, C., \& Labrador, F. (1998). The Self-Fulfilling Prophecy Theory: When Coaches' Expectations Become Reality. In J. Williams (Ed.), Applied Sport Psychology: Personal Growth to Peak Performance (pp. 74-91). Mountain View, CA: Mayfield.

Jussim, L. (1986). Self-Fulfilling Prophecies: A Theoretical and Integrative Review. Psychological 
Review, 93, 429-445. http://dx.doi.org/10.1037/0033-295X.93.4.429

Jussim, L., \& Eccles, J. (1992). Teacher Expectations 2: Construction and Reflection of Student Achievement. Journal of Personality and Social Psychology, 63, 947-961. http://dx.doi.org/10.1037/0022-3514.63.6.947

Jussim, L., Smith, A., Madon, S., \& Palumbo, P. (1998). Teacher Expectations. Advances in Research of Teaching, 7, 1-48.

Karper, W. B., \& Martinek, T. J. (1983). The Differential Influence of Instructional Factors on Motor Performance among Handicapped and Non-Handicapped Children in Mainstreamedphysical Education Classes. Educational Research Quarterly, 8, 40-46.

Mageau, G. A., \& Vallerand, R. J. (2003). The Coach-Athlete Relationship: A Motivational Model. Journal of Sports Sciences, 21, 883-904. http://dx.doi.org/10.1080/0264041031000140374

Martel, D., Brunelle, J., \& Spallanzani, C. (1994). Validation d'un système d'observation du climat d'apprentissage en activité physique. Revue des Sciences de l'Éducation, 20, 493-511. http://dx.doi.org/10.7202/031738ar

Martinek, T. (1980). Stability of a Teacher's Expectations for Elementary School Age Children. Perceptual and Motor Skills, 51, 1269-1270. http://dx.doi.org/10.2466/pms.1980.51.3f.1269

Martinek, T. (1988). Confirmation of a Teacher Expectancy Model: Student Perceptions and Causal Attributions of Teaching Behaviors. Research Quarterly for Exercise and Sport, 59, 118126. http://dx.doi.org/10.1080/02701367.1988.10605488

Martinek, T. (1989). The Psycho-Social Dynamics of the Pygmalion Phenomenon in Physical Education and Sport. In T. J. Templin, \& P. G. Schempp (Eds.), Socialisation in to Physical Education: Learning to Teach (pp. 199-217). Indianapolis, IN: Benchmark.

Martinek, T. (1991). Psycho-Social Dynamics of Teaching Physical Education. Dubuque, IA: Brown and Benchmark.

Martinek, T., \& Johnson, S. (1979). Teacher Expectations. Effect on Dyadic Interaction and SelfConcept in Elementary Age Children. Research Quarterly, 50, 60-70.

Martinek, T., \& Karper, W. (1982). Canonical Relationships among Motor Ability, Expression of Effort, Teacher Expectations in Elementary Age Children. Journal of Teaching in Physical Education, 1, 26-39. http://dx.doi.org/10.1123/jtpe.1.2.26

Martinek, T., \& Karper, W. (1984). The Effects of Non Competitive and Competitive Instructional Climates on Expectancy Effects in Elementary Physical Education Classes. Journal of Sport and Exercise Psychology, 6, 408-421. http://dx.doi.org/10.1123/jsp.6.4.408

Merton, R. (1948). The Self-Fulfilling Prophecy. The Antioch Review, 8, 193-210. http://dx.doi.org/10.2307/4609267

Ministry of Youth and Sports (2015). Article 17 and the Minstry of Education, Article 104-01/ 2015. Institution Project in the Area of Physical Education and Sports Activities, Tunisie $10 / 11 / 2015$.

Nachtscheim, N., \& Hoy, W. K. (1976). Authoritarian Personality and Control Ideologies of Teachers. Alberta Journal of Educational Research, 22, 173-178.

Ntoumanis, N. (2001). A Self-Determination Approach to the Understanding of Motivation in Physical Education. British Journal of Educational Psychology, 71, 225-242. http://dx.doi.org/10.1348/000709901158497

Ntoumanis, N. (2005). A Prospective Study of Participation in Optional School Physical Education Using a Self-Determination Theory Framework. Journal of Educational Psychology, 97, 444-453. http://dx.doi.org/10.1037/0022-0663.97.3.444

Pelletier, L., Seguin-Levesque, C., \& Legault, L. (2002). Pressure from Above and Pressure from 
Below as Determinants of Teachers' Motivation and Teaching Behaviors. Journal of Educational Psychology, 94, 186-196. http://dx.doi.org/10.1037/0022-0663.94.1.186

Pelletier, L., \& Vallerand, R. (1996). Supervisors' Beliefs and Subordonates' Intrinsic Motivation: A Behavioral Confirmation Analysis. Journal of Personality and Social Psychology, 71, 331340. http://dx.doi.org/10.1037/0022-3514.71.2.331

Pieron, M., \& Carreiro Da Costa, F. (1996). Seeking Expert Teachers in Physical Education and Sport. European Journal of Physical Education, 1, 5-18.

http://dx.doi.org/10.1080/1740898960010102

Pieron, M. (1993). Analyser l'enseignement pour mieux enseigner. Paris: Ed. Revue E.P.S.

Pieron, M., Cloes, M., Luts, K., Ledent, M., Pirottini, V., \& Delfosse, C. (1998). Analyse de la prise en considération des caractéristiques individuelles des élèves dans les décisions et les comportements des enseignants experts et débutants. Rapport final d'une recherche réalisée dans le cadre d'une convention passée entre la Communauté française de Belgique et l'Université de Liège (157/96). Liège: ISEPK.

Reeve, J. (2002). Self-Determination Theory Applied to Educational Settings. In E. Deci, \& R. Ryan (Eds.), Handbook of Self-Determination Research (pp. 183-203). Rochester, NY: The University of Rochester Press.

Reeve, J., Bolt, E., \& Cai, Y. (1999). Autonomy-Supportive Teachers: How They Teach and Motivate Students. Journal of Educational Psychology, 91, 537-548. http://dx.doi.org/10.1037/0022-0663.91.3.537

Reeve, J., Deci, E. L., \& Ryan, R. M. (2004). Self-Determination Theory: A Dialectical Framework for Understanding Socio-Cultural Influences on Student Motivation. In D. M. Mclnerney, \& S. Van Etten (Eds.), Big Theories Revisited (pp. 31-60). Greenwich, CT: Information Age Press.

Rosenthal, R. (1974). On the Social Psychology of the Self-Fulfilling Prophecy: Further Evidence for Pygmalion Effects and Their Mediating Mechanisms. New York: MSS Modular Publications.

Rosenthal, R., \& Jacobson, L. (1968). Pygmalion in the Classroom: Teacher Expectation and Student Intellectual Development (p. 47). New York: Holt, Rinehart \& Winston.

Ryan, R. M., \& Deci, E. L. (2007). Self-Determination Theory and the Promotion and Maintenance of Sport, Exercise, and Health. In M. S. Hagger, \& N. L. D. Chatzisarantis (Eds.), Intrinsic Motivation and Self-Determination in Exercise and Sport (pp. 1-19). Champaign, IL: Human Kinetics.

Ryan, R. M., \& Deci, E. L. (2000). Intrinsic and Extrinsic Motivations: Classic Definitions and New Directions. Contemporary Educational Psychology, 25, 54-67. http://dx.doi.org/10.1006/ceps.1999.1020

Ryan, R. M., \& Deci, E. L. (2002). Overview of Self-Determination Theory: An Organismic Dialectical Perspective. In E. L. Deci, \& M. R. Ryan (Eds.), Handbook of Self-Determination Research (pp. 3-33). Rochester, NY: University of Rochester Press.

Sarrazin, P. (2001). Approches socio-cognitives de la motivation appliquée au champ du sport et de l'EPS. HDR.

Sarrazin, P., Tessier, D., \& Trouilloud, D. (2006). Climat motivationnel instauré par l'enseignant et implication des élèves en classe: l'état des recherches. Revue Française de Pédagogie, 157, 147-177. http://dx.doi.org/10.4000/rfp.463

Sarrazin, P., Tessier, D., Pelletier, L., Trouilloud, D., \& Chanal, J. (2006). The Effects of Teachers' Expectations about Students' Motivation on Teachers' Autonomy-Supportive and Controlling Behaviors. International Journal of Sport and Exercise Psychology, 4, 283-301.

Sarrazin, P., Trouilloud, D., \& Bois, J. (2005). Attentes du superviseur et performance sportive de 
pratiquant. Amplitude et fonctionnement de l'effet pygmalion en contexte sportif. Bulletin de Psychologie 1/2005 (Numéro 475), 63-68.

Sarrazin, P., Trouilloud, D., Tessier, D., Chanal, J., \& Bois, J. (2005). Attentes de motivation et comportements différenciés de l'enseignant d'éducation physique et sportive à l'égard de ses élèves: Une étude en contexte naturel d'enseignement. Revue Européenne de Psychologie Appliquée, 55, 111-120. http://dx.doi.org/10.1016/j.erap.2004.06.005

Sarrazin, P., Vallerand, R. J., Guillet, E., Pelletier, R., \& Cury, F. (2002). Motivation and Dropout in Female Handballers: A 21-Month Prospective Study. European Journal of Social Psychology, 32, 395-418.

Sarthou, J. J. (2003). Enseigner l'EPS. De la réflexion didactique à l'action pédagogique. Paris: Editions Actio.

Smith, R. E., Smoll, F. L., \& Hunt, E. (1977). A System for the Behavioral Assessment of Athletic Coaches. Research Quarterly, 48, 401-408.

Snyder, M. (1984). When Belief Creates Reality. Advances in Experimental Social Psychology, 18, 247-305. http://dx.doi.org/10.1016/S0065-2601(08)60146-X

Solomon, G. B., Striegel, D. A., Eliot, J. F., Heon, S. N., Maas, J. L., \& Wayda, V. K. (1996). The Self-Fulfilling Prophecy in College Basketball: Implications for Effective Coaching. Journal of Applied Sport Psychology, 9, 44-59. http://dx.doi.org/10.1080/10413209608406307

Spallanzani, C. (1995). Description de l'effet Pygmalion sur le temps d'apprentissage offert à des élèves en éducation physique au primaire. Avante, 1, 1-18.

Trouilloud, D. (2002). L'effet Pygmalion en Education Physique et Sportive. Réalité, processus médiateurs et variables modératrices de l'influence des attentes de l'enseignant sur la motivation et la performance des élèves. Thèse de Doctorat, Grenoble: Université J.Fourier.

Trouilloud, D., \& Sarrazin, P. (2002). L'effet Pygmalion existe-t-il en éducation physique et sportive? Influence des attentes des enseignants sur la motivation et la performance des élèves. Science \& Motricité, 46, 69-94.

Trouilloud, D., Sarrazin, P., Bressoux, P., \& Bois, J. (2006). Relation between Teachers' Early Expectations and Students' Later Perceived Competence in Physical Education Classes: Autonomy-Supportive Climate as a Moderator. Journal of Educational Psychology, 98, 75-86. http://dx.doi.org/10.1037/0022-0663.98.1.75

Trouilloud, D., \& Sarrazin, P. (2003). Les connaissances actuelles sur l'effet Pygmalion: Processus, poids et modulateurs. Revue Française de Pédagogie, 145, 89-119.

http://dx.doi.org/10.3406/rfp.2003.2988

Trouilloud, D., Sarrazin, P., Martinek, T., \& Guillet, E. (2002). The Influence of Teacher Expectations on Student Achievement on Physical Education Classes: Pygmalion Revisited. European Journal of Social Psychology, 32, 591-607. http://dx.doi.org/10.1002/ejsp.109

Vallerand, R. J., \& Bissonette, R. (1992). Intrinsic, Extrinsic and Amotivational Styles as Predictors of Behavior: A Prospective Study. Journal of Personality, 60, 599-620. http://dx.doi.org/10.1111/j.1467-6494.1992.tb00922.x

Vallerand, R. J. (1997). Toward a Hierarchical Model of Intrinsic and Extrinsic Motivation. In M. P. Zanna (Ed.), Advances in Experimental Social Psychology (pp. 271-360). New York: Academic Press. http://dx.doi.org/10.1016/s0065-2601(08)60019-2

Vallerand, R. J. (2007). A Hierarchical Model of Intrinsic and Extrinsic Motivation for Sport and Physical Activity. In M. S. Hagger, \& N. L. D. Chatzisarantis (Eds.), Intrinsic Motivation and Self-Determination in Exercise and Sport (pp. 255-279). Champaign, IL: Human Kinetics.

Vallerand, R. J., \& Losier, G. F. (1999). An Integrative Analisis of Intrinsic and Extrinsic Motiva- 
tion in Sport. Journal of Applied Sport Psychology, 11, 142-169.

http://dx.doi.org/10.1080/10413209908402956

Vallerand, R. J., Blais, M., Briere, N., \& Pelletier, L. (1989). Construction et validation de l'Echelle de Motivation en Education (EME). Revue Canadienne des Sciences du Comportement, 21, 323-349. http://dx.doi.org/10.1037/h0079855

Weinstein, R. S., \& Middlestadt, S. E. (1979). Student Perceptions of Teacher Interactions with High and Low Achievers. Journal of Educational Psychology, 71, 421-431.

http://dx.doi.org/10.1037/0022-0663.71.4.421

Weinstein, R. S. (1985). Student Mediation of Classroom Expectancy Effects. In J. Dusek (Ed.), Teacher Expectancies (pp. 329-350). Hillsdale: Erlbaum.

Wolfe, M. L., \& Engel, J. O. (1978). Dimensions of Opinion about Teacher-Pupil Relations. The Journal of Experimental Education, 46, 41-45. http://dx.doi.org/10.1080/00220973.1978.11011630

Yee, A. H., \& Frutcher, B. (1971). Factor Content of the MTAI. American Educational Research Journal, 8, 116-133.

Submit or recommend next manuscript to SCIRP and we will provide best service for you:

Accepting pre-submission inquiries through Email, Facebook, LinkedIn, Twitter, etc.

A wide selection of journals (inclusive of 9 subjects, more than 200 journals)

Providing 24-hour high-quality service

User-friendly online submission system

Fair and swift peer-review system

Efficient typesetting and proofreading procedure

Display of the result of downloads and visits, as well as the number of cited articles

Maximum dissemination of your research work

Submit your manuscript at: http://papersubmission.scirp.org/

Or contact ce@scirp.org 